\title{
Genesis of Cocites from North Vietnam: Results of Melt Inclusions Studies in Minerals
}

Panina, L.I.

Institute of Mineralogy and Petrography, 630090 Novosibirsk, Russia.

Introduction. We have studied melt inclusions in cocite minerals of North Vietnam (Lacroix, 1933; Wagner and Velde, 1986; Polyakov et al., 1995) with the aim to determine physicochemical parameters of crystallization and to elucidate whether these rocks can be referred to the lamproite family. We also studied lava breccias of the Sin Cao district, which have a similar chemical composition and consist of juvenile clasts and lapilli with syenite and cocite composition as well as xenogenic fragments submerged into glassy groundmass.

Analytical procedures. To homogenize inclusions, we used a high-temperature (up to $1450 \pm 10^{\circ} \mathrm{C}$ ) heating stage combined with a microscope. The chemical composition of inclusions (glasses and crystalline phases) was determined using "Camebax" microprobe: the X-ray beam diameter was 2.5-3 $\mu \mathrm{m}$, the accuracy of measurement - 1-1.5 wt.\%. The fluid phase composition was determined on Raman spectrometer "Ramanor U-100".

Results of investigations. In the minerals of cocites and lava breccias melt inclusions (glassy and partly crystallized inclusions) with alkaline-basic, syenitic, and carbonatitic compositions have been found. They are often separated, but sometimes are localized in one mineral grain: alkaline-basic inclusions are scattered in the grain, syenitic inclusions tend to its peripheral zones, and carbonatitic inclusions are confined to the peripheral zones and fractures.

The alkaline-basic inclusions are found in olivine and clinopyroxene, and they homogenize at 1320-1265 and $1240-1140^{\circ} \mathrm{C}$, respectively. The inclusions contain glass and daughter phases with chemical composition typical of lamproites: K-feldspar enriched in $\mathrm{BaO}$ and $\mathrm{FeO}$, low-alumina phlogopite, and $\mathrm{TiO}_{2}$ - and $\mathrm{Cr}_{2} \mathrm{O}_{3}$-rich magnetite. The composition of inclusion glass (Table 1) varies from high-magnesian low-alumina, similar to the composition of olivine and diopside-leucite lamproites (an 1,8$)$ to noticeably $\mathrm{Al}_{2} \mathrm{O}_{3}$-enriched (15-17\%) and $\mathrm{MgO}$-depleted (2-5 wt.\%). The alkalis are dominated by $\mathrm{K}$, and less often the contents of $\mathrm{Na}$ and $\mathrm{K}$ are equal.

The syenitic inclusions are found in olivine, clinopyroxene and phlogopite, and they homogenize at 1100 $1060^{\circ} \mathrm{C}$. The composition of glassy inclusions (Table 2) ranges from trachyte to dacite-rhyolite. The total of alkalis is dominated by either $\mathrm{K}$ or $\mathrm{Na}$. The chemical composition of glassy inclusions is similar to that of interstitial glass in lava breccias, but they are slightly richer in $\mathrm{Al}$ (Table 2, an 10-12).

The carbonatitic inclusions are very scarce, and they were found in clinopyroxene and apatite of cocites. They contain (wt.\%, $\mathrm{n}=5$ ): $7-10.8 \mathrm{SiO}_{2}$, to $0.8 \mathrm{TiO}_{2}, 2.4-4 \mathrm{Al}_{2} \mathrm{O}_{3}, 1.5-3.6 \mathrm{FeO}, 1.4-4.3 \mathrm{MgO}, 31-38 \mathrm{CaO}$, $0.4 \mathrm{Na}_{2} \mathrm{O}, 1.6-2.1 \mathrm{~K}_{2} \mathrm{O}, 0.1 \mathrm{BaO}$, to $1.5 \mathrm{P}_{2} \mathrm{O}_{5}$ and $2.2 \mathrm{SrO}$. The daughter phases of the inclusions are apatite, albite-oligoclase, and magnetite.

\section{Conclusions.}

1. The presence of compositionally different melt inclusions in minerals suggests that cocites and lava breccias were, most likely, the result from mixing of magmas with alkaline-basic and syenitic compositions. The contrasting composition of juvenile lapilli and clasts in lava breccias is indirect evidence of this conclusion.

2. The high-magnesian low-alumina composition of some inclusions suggests that the alkaline-basic magma initially might have had a lamproitic composition. The potential participation of lamproitic melt in formation of cocites is also indicated by some similar features of minerals from lamproites (Mitchell and Bergman, 1991) and cocites (Polyakov etc., 1997) as well as compositions of crystalline phases from inclusions in cocites. 
3. When mixing with syenitic melts, lamproitic magma was enriched in salic components, which is confirmed by a wide occurrence of melt inclusions with intermediate composition (between lamproites and syenites) in minerals of cocites and lava breccias. In Fig. 1, reflecting the position of lamproites and Kbasaltoids (Panina, 1995), these inclusions fall into the intermediate field and have abruptly directed trends of transformation, which is typical of mixing media.

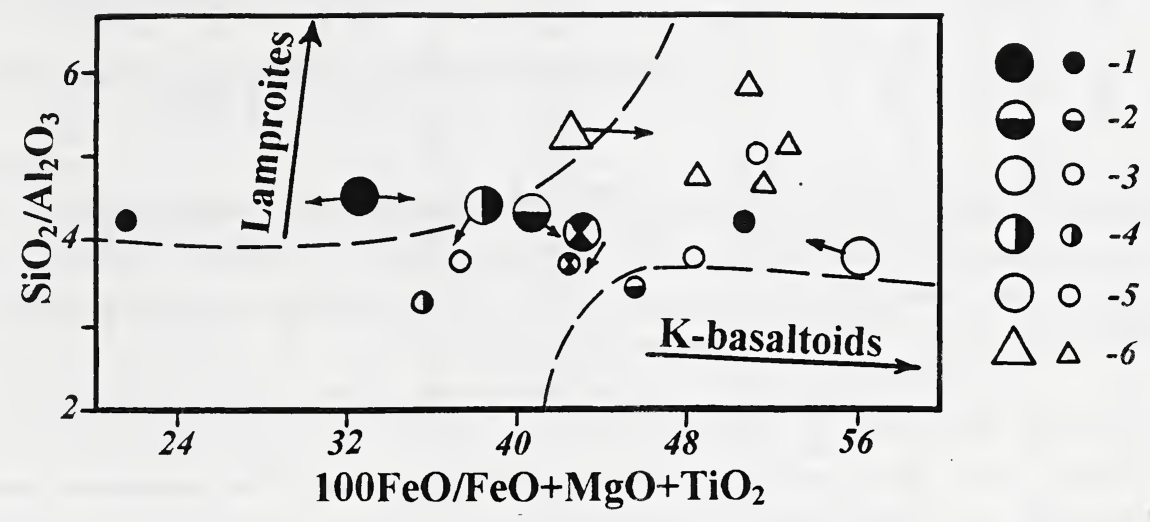

Fig. 1

1-5 - different samples of cocites and inclusion glasses. respectively. 6 - lava breccias and inclusion glasses. respectively. The pointers show evolution trends for melt diring crystallization. Dashed lines counter the fields of typical lamproites and K-basaltoids.

4. The presence of the direct and reverse zoning in the main minerals (Polyakov et al., 1997) indicates that magma mixing was not homogeneous, and phenocrysts also occurred: in lamproitic magmas - olivine, clinopyroxene, and phlogopite; in syenitic magma - Fe-rich clinopyroxene and phlogopite, K-feldspar, sphene, and Ti-rich garnet. Phenocrysts seem to have overgrown from already mixed meits. According to homogenization temperatures of inclusions, olivine in alkaline-basic magma started to crystallize above 1320 , and clinopyroxene - at $1240-1170^{\circ} \mathrm{C}$. Most of phenocrysts in syenitic magma crystallized at $1100-$ $1060^{\circ} \mathrm{C}$.

5. The appearance of the carbonatitic melt inclusions most likely suggests that the separation of carbonatitic melt noticeably enriched in $\mathrm{P}$ and $\mathrm{Sr}$ occurred at the late crystallization stages of mixing magma. It is worth noting that there is a possibility of detecting carbonatites in the district studied.

6. Among volatiles in syenitic magma the most important was nitrogen (up to 100 mole \%), while $\mathrm{Cl}$ was negligible (up to $0.64 \mathrm{wt} \%$ ). Of appreciable significance in alkaline-basic melts along with $\mathrm{Cl}$ (up to 0.4 wt.\%) was $\mathrm{SO}_{3}$ (up to $0.86 \mathrm{wt} . \%$ ) and, perhaps, of fundamental $-\mathrm{CO}_{2}$, which is indirectly evidenced by separation of carbonatitic melt.

\section{References}

Lacroix, A., 1933, Contribution a la connaissance de la composition chimique et mineraloique des roches eruptries de L'Indochine: Bull.Serv.Geol.Indochine, 20(3), p. 98-99.

Wagner. Ch.. and Velde, D.. 1986, Lamproites in North Vietnam? A re-examination of cocites: The Journal of Geology, 94. p. $770-776$.

Polyakov, G.V.. Nguen Trong Yem. Balykin. P.A. et al.. 1997. Ultrapotassic basic rocks of North Vietnam (cocites). their geologic setting, specific features of composition and origin in connection with the problem of lamproites: Geologiva $\mathrm{i}$ Geofizika, 38(1). p. 148-158 (in Russian).

Polyakov, G.V.. Nguen Trong Yem. Balykin. P.A., et al., 1995, Geology and substance composition of the cocites of North Vietnam: Extended Abstracts of Sixth International Kimberlite Conference, Novosibirsk, p. 449-451.

Mitchell. R.H. Bergman, S.C., 1991, Petrology of lamproites: New York. Plenum Press, 447 pp.

Panina. L.I., 1995. Physico-chemical conditions of crystallization of low-titanium lamproites of Aldan: Extended Abstracts of Sixth International Kimberlite Conference. Novosibirsk. p. $+21+23$. 


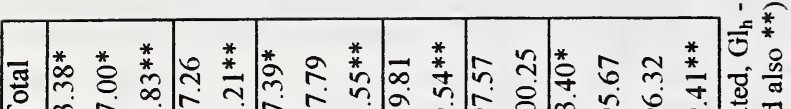

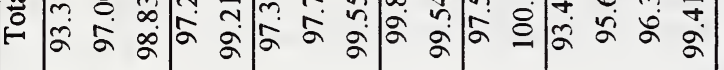

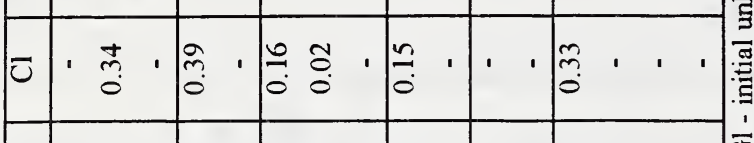

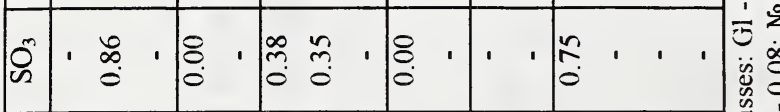

夰, 声 $\begin{array}{lllllllllllllllll}1 & 0 & 0 & 0 & 0 & 0 & 0 & 0 & 0 & 0 & 0 & 0 & 0 & 0 & 0\end{array}$

: สำ

0 舫

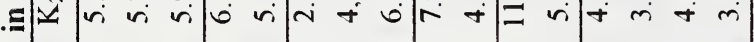

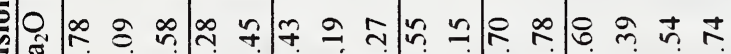

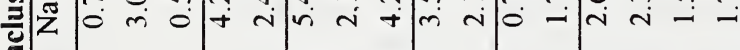

ప

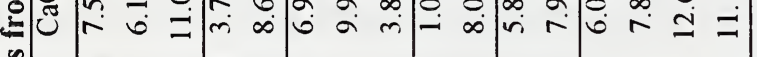

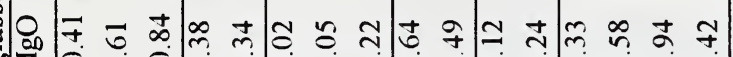

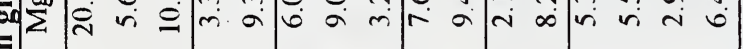
o $\hat{\infty}$ 南

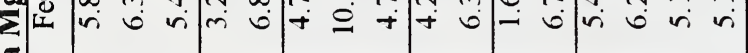
0

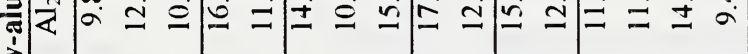

-

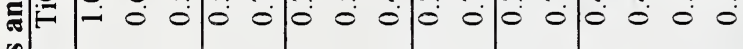

-

\begin{tabular}{|c|c|c|c|c|c|c|}
\hline & & & & & & \\
\hline$=$ & $-\rightarrow-$ & -- & $n \sim N$ & $\sim-$ & $n-$ & $-N--$ \\
\hline$\vec{b}$ & 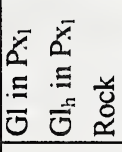 & 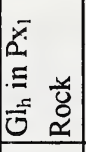 & 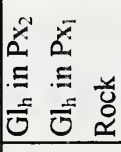 & 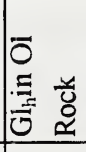 & 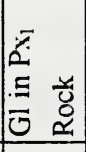 & 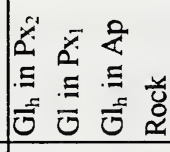 \\
\hline 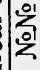 & $-\sim m$ & $+n$ & $0 \sim \infty$ & $\alpha=$ & $=\simeq$ & $\cong \pm \cong \simeq$ \\
\hline & نُ & ני & نُّ & ن & ن & 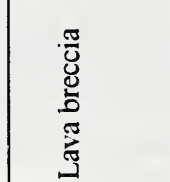 \\
\hline
\end{tabular}

ฐึ

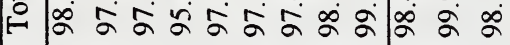

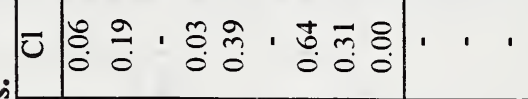

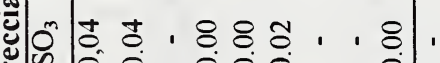
范

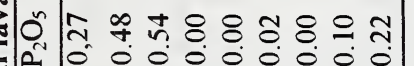
(1) 을

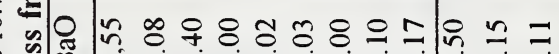
先

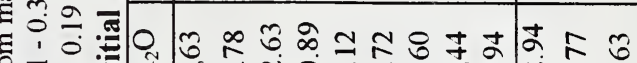

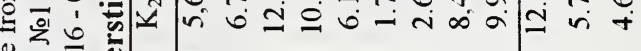
竞 .

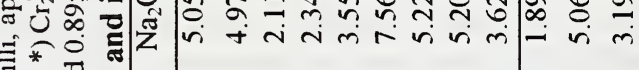

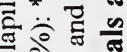

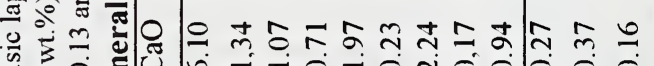
要 둥 说. 萡

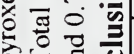

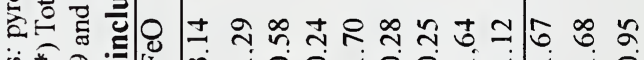

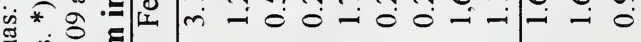
:

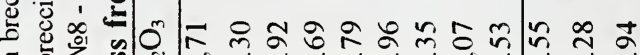

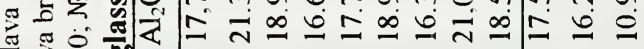

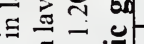

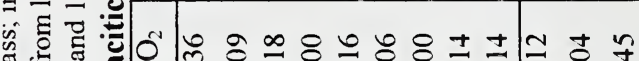
苟

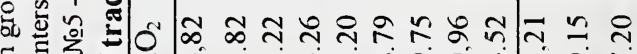

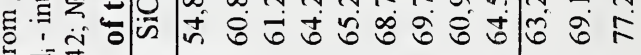

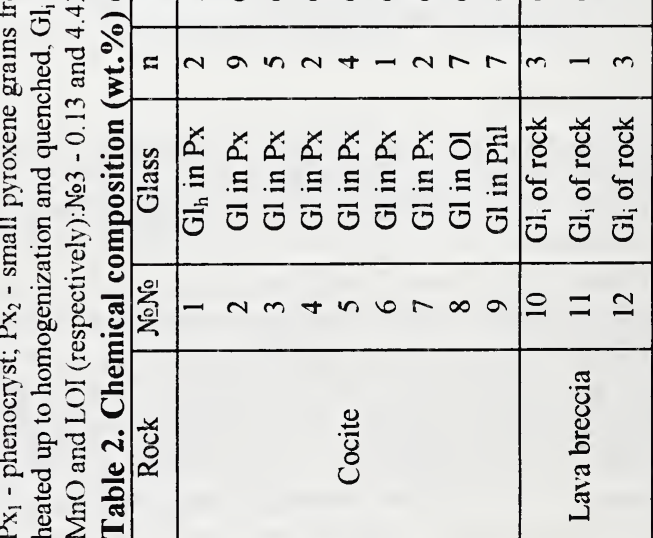

